Avrupa Bilim ve Teknoloji Dergisi

Sayı 27, S. 902-910, Kasim 2021

(C) Telif hakkı EJOSAT'a aittir

Derleme Makalesi
European Journal of Science and Technology

No. 27, pp. 902-910, November 2021

Copyright C 2021 EJOSAT

Review Article

\title{
Besin Alerjileri ve Mikrobiyota
}

\author{
Jale Çatak $^{1^{*}}$, Ayşenur Demirci ${ }^{2}$, Mustafa Yaman ${ }^{3}$ \\ 1* İstanbul Sabahattin Zaim Üniversitesi, Sağlık Bilimleri Fakültesi, Beslenme ve Diyetetik Bölümü, İstanbul, Türkiye, (ORCID: 0000-0002-2718-0967), \\ jalecatak@gmail.com \\ 2 İstanbul Sabahattin Zaim Üniversitesi, Sağlık Bilimleri Fakültesi, Beslenme ve Diyetetik Bölümü, İstanbul, Türkiye (ORCID: 0000-0002-2665-6927), \\ dyt.aysenurdemirci@gmail.com \\ 3 İstanbul Sabahattin Zaim Üniversitesi, Sağlık Bilimleri Fakültesi, Beslenme ve Diyetetik Bölümü, İstanbul, Türkiye (ORCID: 0000-0001-9692-0204), \\ mustafa.yaman@izu.edu.tr
}

(İlk Geliş Tarihi 4 Mayıs 2021 ve Kabul Tarihi 9 Kasım 2021)

(DOI: 10.31590 /ejosat.932606)

ATIF/REFERENCE: Çatak, J., Demirci, A. \& Yaman, M. (2021). Besin Alerjileri ve Mikrobiyota. Avrupa Bilim ve Teknoloji Dergisi, (27), 902-910.

\section{Öz}

Ülkemizde ve dünyada son yıllarda besin alerjilerinin yaygınlığında artış gözlenmektedir. Ülkelerin beslenme kültürlerine bağlı olarak alerjen besin maddelerinde değişiklik olsa da, çoğunlukla sekiz besin alerjiye sebebiyet vermektedir. Besin alerjileri IgE aracılı olduğu gibi IgE aracılı olmayan mikst tip reaksiyonlar ile de gerçekleşmektedir. IgE kaynaklı reaksiyonlar yaşamı tehdit edebilen önemli bir halk sağlığı sorunudur. Süt çocuklarında besin alerjilerine neden olan faktörlere bakıldığında, ailede atopi öyküsünün olmasının yanı sıra, çevresel maruziyetler, mikrobiyotanın çeşitliliği, miktarı ve dengesinde meydana gelen değişikliklerin tetiklediği düşünülmektedir. Besin alerjilerin önlenmesi veya seyrinin hafifletilmesinde mikrobiyotanın gelecek vaat ettiği düşünülmektedir. Bu derlemede bağırsak mikrobiyotası ile besin alerjileri arasındaki ilişkiye yönelik bir literatür çalışması yapılmıştır.

Anahtar Kelimeler: IgE-Aracılı Besin Alerjileri, Bağırsak Mikrobiyotası, Probiyotikler, Tanı Testleri.

\section{Food Allergies and Microbiota}

\begin{abstract}
The prevalence of food allergies in our country and the world has increased in recent years. Although there are changes in allergen nutrients depending on the nutritional cultures of the countries, mostly eight foods cause allergies. Food allergies occur with IgEmediated as well as non-IgE-mediated mixed-type reactions. IgE-induced reactions are an important public health problem that can be life-threatening. Considering the factors that cause food allergies, it is thought that besides the family history of atopy, environmental exposures, changes in the variety, amount, and balance of the microbiota are triggered. Microbiota is believed to have a promise in preventing or alleviating the course of food allergies. In this review, a literature study was conducted on the relationship between intestinal microbiota and food allergies.
\end{abstract}

Keywords: IgE-Mediated Food Allergies, Intestinal Microbiota, Probiotics, Diagnostic Tests.

${ }^{*}$ Sorumlu Yazar: jalecatak@gmail.com 


\section{Giriş}

Besin alerjisi ilk olarak M.Ö. 100. yılda Lucretus tarafından besin tüketiminin ardından gelişen istenmeyen reaksiyonlar olarak tanımlanmıştır (Akoğlu ve Oruç, 2018). Besin maddelerine karşı oluşan ters reaksiyon, gıdanın alımından sonra ortaya çıkan herhangi bir anormal reaksiyondur (Sampson ve Burks, 2009). Tarihte 2000 yıldan daha uzun süredir, besin alerjilerine yönelik çalışmalar yapılmıştır. Besin alerjilerine yönelik ilk tanımlamalardan birini ilk olarak Hipokrat yapmıştır. Bundan 2000 y1l önce Hipokrat inek sütüne karşı olumsuz reaksiyonların olduğunu belirtmiştir. 1921 'de ise Prausnitz ve Kustner ilk kez balık alerjisi reaksiyonunu tanımlamıştır (Özçeker ve Tamay, 2015; Boyce ve ark., 2011).

Besin alerjileri veya intoleransları beslenme kaynaklı görülen sağlık problemlerinin başında gelmektedir (Loh ve Tang, 2018). Ülkemizde 15 yaş ve üstü bireylerde en çok görülen hastalık türleri incelendiğinde \%10,8 ile atopik hastalar yer alır (Türkiye İstatistik Kurumu, 2016). Besinlere karş1 geliştirilen reaksiyonlar immunolojik reaksiyonlar ve immunolojik olmayan reaksiyonlar olarak ikiye ayrılır. Besin intoleransı; besinin bileşenlerine karşı gösterilen hassasiyet olarak tanımlanır. Farmakolojik, toksik, metabolik ve tanımlanmayan mekanizmaların intolerans gelişimine neden olduğu düşünülür. İntoleransta vücudun savunma sistemi devreye girmez. Besin intoleransları, gastrointestinal sistemde (GİS) fonksiyon bozuklukları oluşturarak belirtiler verebilmektedir. Semptomlar tüketilen besin miktarına bağlı olmakla birlikte yavaş gelişir ve tehlikeli değildir. Besin alerjileriyse immün sistem aracılığıyla besinlere karşı gösterilen hipersensitivite reaksiyonları olarak tanımlanır. Antijen özellik gösteren besinin sindirilmesinden sonra immünolojik olarak tetiklenen semptomların gelişimini ifade eder (Özcan ve ark., 2015).

Epidemiyolojik çalışmalar coğrafi bölgeye, yaşa ve çalışma metodolojilerine göre değişkenlik gösterse de genel bir sonuç olarak besin alerjisinin dünya genelinde yaygınlığında bir artış söz konusudur (De Martinis ve ark., 2020). Dünyada olduğu gibi ülkemizde de son yıllarda alerjik hastalıklarda artışlar vardır. Besin alerjilerinin ülkemizdeki sıklı̆̆ının saptanması, risk altındaki bireylerin saptanması, gıda güvenliğin sağlanmas1, toplumun bilinçlendirilmesi ve koruyucu önlemlerin alınması gerekmektedir (Kvenshagen ve ark., 2009).

En yaygın görülen besin alerjileri arasında inek sütü, tavuk yumurtası, yer fistığı, ağaç yemişleri, soya, buğday, balık, kabuklu deniz ürünleri yer alır (Lopes ve Sicherer, 2020; Seth ve ark., 2020).

Besin alerjilerinin tedavilerinde eliminasyon diyetleri ve oral immünoterapiler yer almaktadır. (Szépfalusi ve ark., 2015). Son yıllarda yapılan çalışmalarda, mikrobiyotanın besin alerjilerinin gelişiminin önlenmesinde ve seyrinde yararlı etkileri olduğu bildirilmiştir (Molloy ve ark., 2013).

\section{Besin Alerjileri}

Besin alerjisi, vücuda alınan besinlere immünolojik mekanizmalar aracılığı ile gösterilen besinlere karşı oluşan istenmeyen reaksiyonlardır (Begen ve ark., 2017; Johansson ve ark., 2004; Koca ve Akçam, 2015). Alerji; vücut için alerjen olan inorganik veya organik maddelerin tüketilmesi, solunmas1, deriyle doğrudan temas yollarıyla karşılaşması sonucu organizmanın savunma mekanizmasının aşırı çalışma halidir
(Sicherer ve Sampson, 2018). Alerjen besin maddesi ile karşılaşılması sonucu gösterilen aşırı duyarlılık reaksiyonları; savunma sisteminin önemli bir parçası olan immünoglobulin $\mathrm{E}$ (IgE) aracılığıyla, T hücreleri aracılığıyla (IgE aracılı olmayan) veya hem IgE aracılı hem de hücre aracılı olan mikst reaksiyonları kapsamaktadır (Begen ve ark., 2017; Öztürk ve Besler, 2012). Bağışıklık sistemi, gıda alerjilerinde, gıda içerisindeki belirli bir maddeye özel olarak ya da bir katkı maddesine karşı antikor üreterek reaksiyon göstermektedir (Tokuç, 2017). Besinlere karşı gelişen reaksiyonların sınıflandırılması Şekil 1' de gösterilmiştir.

Duyarlı bir kişi, alerjen ile karşılaştığında dermatit bulgu, kaşıntı, burun tıkanıklığı, GİS sistemde rahatsızlıklar, kızarıklık, şişlik, nefes almada zorluk ve anafilaksi gibi klinik tablolar ortaya çıkar (Öztürk ve Besler, 2012). Anafilaktik şok ciddi ve hayatı tehdit eden reaksiyonlar arasındadır (Gübür, 2012).

\subsection{Epidemiyolojisi}

Besin alerjilerinin görülme insidansı dünya genelinde son on yılda önemli bir artış göstermiştir (Loh ve Tang, 2018). İnsidansta olan bu artışın belirlenmesi farklı nedenlerle zor olmaktadır (Lopes ve Sicherer, 2020). Ülkemizde bölgelere göre dağılımına bakıldığında, Marmara ve Ege bölgesinde daha çok süt alerjisi görülürken, Karadeniz, Akdeniz, İç Anadolu ve Doğu Anadolu Bölgelerinde ise yumurta alerjisinin sıklığ bulunmuştur. Bölgeler arası görülen farklılıkların sebebi, toplumun beslenme alışkanlıklarından ve pişirme/işleme yöntemlerinin farklılığından kaynaklanmaktadır (Akay ve Yılmaz 2020; Paykoç, 2017; Sicherer ve Sampson 2018).

Çünkü yaygınlık oranlarının tahminleri toplumların beslenme alışkanlıklarına, coğrafi konumlarına, yaş gruplarına ve uygulanan çalışma yöntemlerine göre değişmektedir. Ancak genel bir sonuç alerji prevalansında artış olduğudur (Loh ve Tang, 2018).

$\mathrm{Bu}$ ciddi artışın nedenlerinden bazıları, genetik olarak duyarlı kişilerin modern yaşam tarzı ve besin seçimleri olarak bildirilmiştir. (Lopes ve Sicherer, 2020). Nüfusa dayalı olarak yapılan epidemiyolojik çalışmalarda; obezite, anne ve bebek beslenme bileşenleri, ek gıdaya başlama zamanı, hijyen hipotezi gibi faktörlere bağlı olarak alerjilerin görülmesinde riskler oluşabildiğini göstermektedir (Sicherer ve Sampson, 2018).

Gıda alerjisinin bir halk sağlığı sorunu olduğu ve yaklaşık 6 milyon çocuğun bu durumdan etkilendiği bildirilmiştir (Kadığlu, 2017). Yaşa göre besin alerjisi prevelansına bakıldığında, bebeklerde ve çocuklarda \%3,9- \%8, yetişkinlerde ise \%6,6 - \%10 aralığında saptanmıştır (Epöztürk, 2021). Dünya genelinde ülkelerde en çok rastlan alerjen besinler; Türkiye'de findık, Amerika Birleşik Devletleri ve İsviçre'de yer fistığı, İsrail'de susam, Kore'de ceviz ve İspanya'da ağaç yemişleridir (Lee, 2017; Sackesen, 2019).

\subsection{Patofizyolojisi}

Kanda, kendine özgü antikor oluşturup, alerjik reaksiyonlar gelişmesine neden olan maddelere alerjen denir (Öztürk ve Besler, 2012; Yürük, 2020). Alerjen maddelere çeşitli yollardan maruz kalınabilir. Alerjen maddelerin vücuda alım miktarına karşı tolerans gösterme oranı kişiden kişiye farklılık gösterir (Türkiye Ulusal Alerji ve Klinik İmmunoloji Derneği, 2021). Besin alerjileri, genetik olarak yatkın bireylerde immun sistemin farklılaşması, mukozal bariyerin tam fonksiyon görememesi veya oral toleransın bozulması sonucunda oluşur (Keet ve Wood, 2011). Bunun sonucu olarak patojenlere karşı savunma sırasında 
kullanılan dendritik hücreler aktive edilerek enflamatuar sitokinler salınır. Besin protein antijenine karşı gelişen, immün sistemin anormal bir yanıtı olarak tanımlanmaktadır (Anvari ve ark., 2019) IgE aracilı ve IgE aracilı olmayan ve mikst tipleri vardır. En tehlikeli klinik tablolar IgE aracılı olan tipinde görülür (Boyce ve ark., 2011, Dyer ve Gupta, 2013).

\subsubsection{Bağırsak Bariyeri}

GİS, tek katlı silindirik epitel hücreleri arasında sıkı bağları sayesinde bir bariyer olarak fonksiyon görür ve antijenik özelliklere sahip protein ve büyük makro moleküllerin geçişine engel olur. Gastrointestinal mukozal bariyer fiziksel (s1k1 epitel hücre aralıkları, mukus, asitler ve enzimler) immünolojik kompleks bir yapıya sahiptir. Böylece non-immünolojik mekanizmasının besin alerjisi gelişimini önlemede olduğu düşünülmektedir.

Besin alerjisi gelişimini engellemede gastrointestinal sistem de görevli immun sistem komponentleri doğal immun sistem elemanları (makrofajlar, Toll like reseptörler, polimorfonükleer lökositler, epitel hücreleri, doğal öldürücü hücreler) ve kazanılmış immun sistem elemanları (intraepitelyal lenfositler, lamina propriada yerleşik lenfositler, Peyer plakları, sitokinler ve antijen spesifik sekretuar immünoglobulin A) yer alır. Bariyer fonksiyonunda bozulma ve mide $\mathrm{pH}$ 'sının nötralizasyonu besin alerjisinin gelişimine yardımcı olabilir. Benzer şekilde, mukozal bariyerin, enzimatik aktivitenin ve sekretuar IgA savunma sisteminin tamamen olgunlaşmamasının bebeklikte artmış besin alerjisinin görülme sıklığının artmasında sorumlu olduğu düşünülmektedir (Bayram, 2011; Sampson ve ark., 2009).

\subsubsection{Oral Tolerans}

Gastrointestinal sistem yüzeyini kaplayan epitellerin altındaki gevşek bağ dokusunda lenfosit ve antijen hücreler yer alır. İntestinal yüzeyde besinin proteine maruz kalmasına rağmen az sayıda bireyde besin alerjisi görülür. $\mathrm{Bu}$ durum oral tolerans geliştirmesine bağlıdır (Johnston ve ark., 2014). Besin hipersensitivite reaksiyonlarının engellenmesinde oral tolerans çok önemlidir (Satitsuksanoa ve ark., 2018).

\subsection{Alerjen Besin Maddeleri}

NIAID (National Institute of Allergy and Infectious Diseases) tarafından yayınlanan bir raporda çok sayıda (170 adet) besinin alerjik olabileceği bildirilmiştir. Yapılan prevalans çalışmalarında alerjik reaksiyonlara en sık neden olan besinler ortaya koyulmuştur (Nwaru ve ark., 2014). Bu besinler "süt (\%6), yumurta $(\% 2,5)$, fistık $(\% 0,4)$, soya $(\% 1,5)$, buğday $(\% 1,5)$, balık $(\% 2,2)$ ve kabuklu deniz ürünleridir $(\% 2,2)$ " (Prescott ve ark., 2013). EAACI'nin (Avrupa Alerji ve Klinik İmmünoloji Akademisi) besin alerjisi için yayınlamış olduğu rehberde besin alerjisinin yetişkinlerde \%5,1, çocuklarda \%6,9 görüldüğü bildirilmiştir (Demir ve Ulusoy, 2017). Çocukluk döneminde ortaya çıkan besin alerjileri, buğday, süt, yumurta, soya ve fistık alerjisi iken; yaşamın herhangi bir döneminde ortaya çıkabilen besin alerjileri, kuruyemiş, balık ve deniz ürünleridir (Faber ve ark, 2018).

Sebze ve meyvelere karşı görülen alerjilerin klinik tablosu daha hafif seyreder ve daha az görülür. Meyve ve sebzeler başta olmak üzere, besinlerin ham veya çiğ olarak tüketilmesi alerjik reaksiyonun gelişimini hızlandırabilirken, iyi piştiğinde alerjik reaksiyon durumu değişebilmektedir (Ho ve ark., 2014).

Isıl işlem uygulaması, besinlerin peptit bağlarının hidrolize olmasına, disülfit bağlarının yeniden yapılanmasına, denatürasyona ve başka bileşenler (lipit, karbonhidrat vb.) ile reaksiyona girmesine neden olmaktadır. Isıya bağlı olarak antijen değişimi; uygulanan sıcaklık derecesine ve süresine, proteinlerin yapısal özelliklerine ve bulunduğu ortamın fizikokimyasal özelliklerine bağlı olarak değişiklik göstermektedir. Isıl işlem, aminoasitler ve karbonhidratların, Maillard reaksiyonu gibi çeşitli reaksiyonlara girmesine sebep olmaktadır. $\mathrm{Bu}$ durum konformasyonel epitoplarını değiştirebilmekte, yeni $\operatorname{IgE}$ bağlanma bölgeleri oluşturabilmektedir. Isıl işlem uygulaması, alerjenik yapıyı azaltmakta veya önceden mevcut olmayan bölgeleri açığa çıkararak alerjenik yapının artmasına neden olabilmektedir (Özcan ve ark., 2015; Güzelsoy, 2021).

Alerjen olan besinler dışında dikkat edilmesi gereken diğer bir nokta alerjen besinin başka besin ile olan çapraz reaksiyonudur (Faber ve ark., 2018). Çapraz reaktif besin alerjileri; lateks, huş ağacı poleni, profilinler nedeniyle gelişir (Tokuç, 2017). Polen alerjileri, bitkisel besinler ile alerji gelişimine sebep olur (Floch ve Narayan, 2002).

\subsection{1. Çapraz, Reaktif Gıda Alerjenleri}

IgE-aracılı besin alerjenleri genellikle 2 yolla oluşur. Kişi GİS yolla primer olarak o besine karşı duyarlıdır veya kişi daha önce genellikle bitki kökenli polenlere karşı primer olarak duyarlıdır. Daha sonra ortak çapraz reaksiyon veren antijenik protein yapıları nedeniyle taze sebze ve meyvelere karşı sekonder olarak semptomlar ortaya çıkar (Yıldız, 2021).

Besin alerjilerinin doğal seyri ve besin alerjenleri ile çapraz reaksiyonlar Tablo 1' de verilmiştir. Yumurta, süt ve soya gibi besinlere ait alerjik reaksiyonlar genellikle 1-2 yaşından sonra geçebilir. Fındık, yer fıstığı, balık ve kabuklu deniz ürünlerine karşı oluşan reaksiyonlar ise yaşam boyu devam edebilir (Muraro ve ark., 2014). Süt alerjisi olan çocukların \%20' sinde dana eti alerjisi, dana etine alerjisi olan çocuklarda da süt alerjisi görülmektedir. İnek sütü alerjisi olanların büyük çoğunluğu (\%90), keçi, manda ve koyun sütlerine karş1 da reaksiyon gösterirler. Aynı şekilde tavuk yumurtasına alerjisi olan bir kişinin diğer yumurta türlerine alerji gösterme olasılığı yüksektir. Kabuklu yemişler, deniz ürünleri ve tahıllar kendi aralarında değişen oranda çapraz reaksiyon gösterebilirler (Yazıcı ve Özkaya, 2020). Alerji testlerinde, bir besine klinik olarak bulgu olmaksızın test sonucunda alerjik çıkabilir. Bu durum çapraz reaksiyon ile alakalıdır (Demir, 2019). 


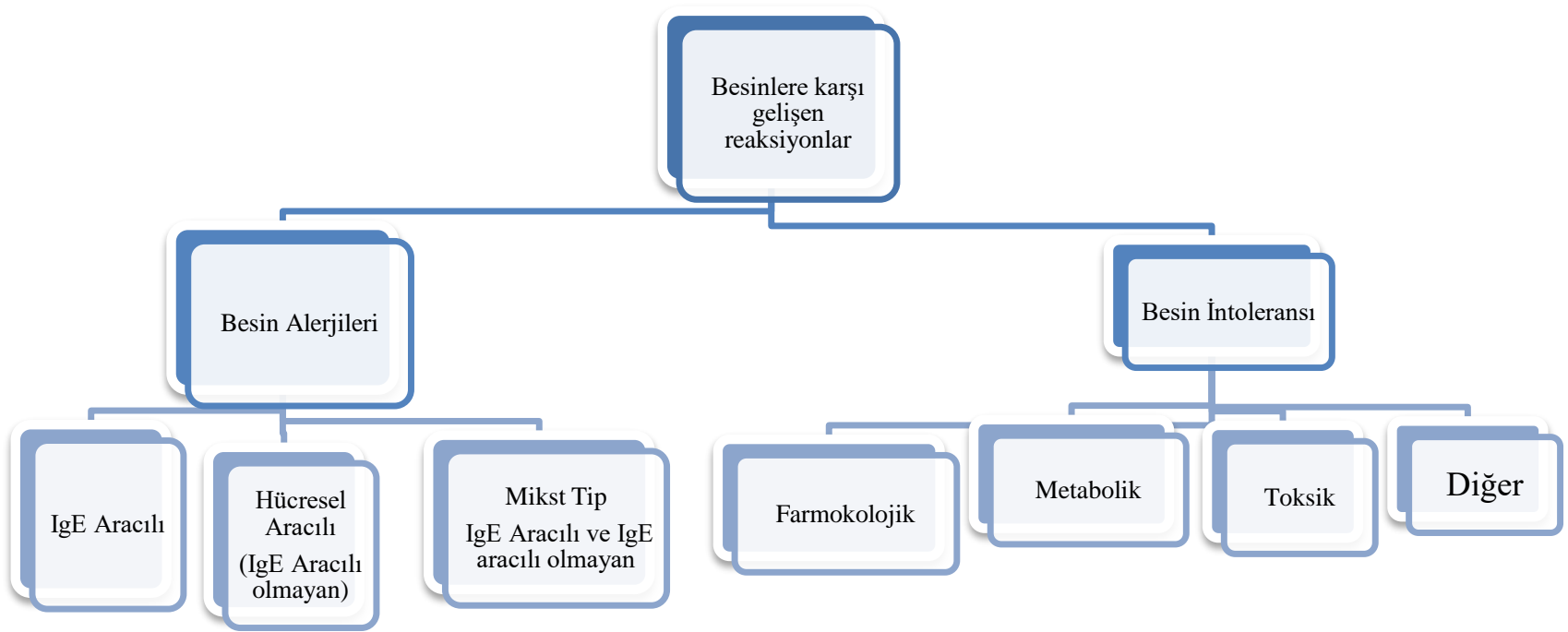

Şekil 1. Besinlere Karşı Gelişen Reaksiyonların Sınıflandırılması (Akbulut, 2016).

\subsection{Besin Alerji Testleri}

Besin alerjilerinin tespitinde hastanın şikâyetleri ve semptomları göz önüne alınarak yapılacak teste karar verilir. Klinikte kullanılan alerji testleri temel olarak in vivo ve in vitro testler olarak ikiye ayrılır (Akan A. (2016). Yaygın olarak kullanılan testler; Deri Prick Testi (DPT), Atopi Yama Testi, RAST Test (Spesifik IgE Tayini), İntradermal Deri Testleri, İntragastral Provakasyon Testi, Endoskopi ve Histoloji, bağırsak mukozası biyopsisi tanıda kullanılan laboratuvar testleridir. Laboratuvar testlerinin dışında tanıyı sağlamak için besin eliminasyon diyetleri ve oral besin yükleme testi uygulayarak tanının daha doğru konulmasını sağlar (Özçelik, 2019; Akbulut, 2016).

Son zamanlarda besin alerjisi tanısında mide suyu analizi, bazofil histamin salınım testi, endoskopik alerjen provokasyonu, lenfosit stimülasyon testi, mediatör salınım testi kinesiyoloji testi, fasiyal termografi, saç analizi, elektrodermal test (Vepa), sitotoksisite testleri gibi çeşitli yöntemler de kullanılmaktadır (Köken, 2019). Besin intoleranslarını belirlemede; ALCAT, LEAP MRT, ELISA, MICROARRAY-ELISA testleri uygulanmaktadır. Bilimsel değeri olmayan birçok ticari testin yaygın olarak kullanımı mevcuttur. $\mathrm{Bu}$ testler tutarsız sonuçlar verebildiği için güvenilir değildir.

\subsection{Besin Alerji Tedavi Yöntemleri}

Besin alerji tedavisinde, temel olarak ilk uygulanan basamak tıbbi beslenme tedavisidir. Trbbi beslenme tedavisi eliminasyon diyetlerine dayanmaktadır. Eliminasyon diyetleri alerjen besin maddelerinin diyetten çıkarılması esasına dayanır. Hasta veya hastadan sorumlu kişiler, alerjen besin maddesi, alerjen besin maddesi ile çapraz reaktiviye sahip besinler ve alerjen besin maddesinin bulunma ihtimali olan paketlenmiş ürünlerin etiketlerinin okunması konusunda bilgilendirilmelidir. Diyetten elimine edilen besin maddelerinin yerine alternatif besinler belirlenerek diyet oluşturulmalıdır. Hastalar izlenerek makrobesinler ve mikrobesinler değerlendirilmeli ve eksik görülen besinler, farklı besin veya besin takviyeleriyle giderilmelidir. Tıbbi beslenme tedavisi haricinde, bağırsak bariyerinin güçlendirilmesi ve probiyotikler ile desteklenmesinin hastalığın seyri konusunda katkı sağladığı bildirilmiştir (Frith ve Katelaris, 2019; Krogulska ve Wood, 2020; Akyüz, 2018).

\subsection{Besin Alerjilerinin Olası Gelişim Nedenler}

Atopi oluşumunda, kalıtım ve çevresel etmenler rol oynamaktadır. Yapılan çalışmalarda atopik bireyin, ebeveynlerinin her ikisi de alerjikse çocuğun alerjik olma olasılığı \%67'dir, ebeveynlerin biri alerjikse bu oran \%33'e düşmektedir. Duyarlanmanın nasıl ve ne zaman ortaya çıtı $\breve{g}_{1}$ halen araştırılmaktadır. Duyarlanmanın anne karnında başlayabileceği gibi; doğum yolu, tamamlayıcı beslenmeye geçiş zamanı, emzirme süresi, fazla hijyenik ortamda büyüme ve disbiyozis gibi çeşitli etmenlerle ilişkisi bildirilmiştir (Shroba ve ark., 2019; Canani ve ark., 2015).

\section{Alerji ve Mikrobiyota}

Besin alerjisi, besinlere karşı immun sistem aracılığıyla gösterilen anormal bağışıklık yanıtı olarak tanımlanır. Mikrobiyota ile mikrobiyomun aynı anlama geldiği düşünülmektedir veya ikisinin anlamı birbiriyle karıștırılmaktadır. Mikrobiyota, vücudun farklı bölgelerinde bulunan mikroorganizma popülasyonlarını (cilt mikrobiyotası, bağırsak mikrobiyotası vb.) ifade ederken mikrobiyom ise, vücutta yaşayan bütün mikroorganizmalar ve onların genetik materyalini ifade eder (Khanna ve Tosh, 2014). Mikroorganizmalar, insan vücudunda gastrointestinal sistem, ürogenital sistem, orofaringeal alan, hava yolları, deri, kan ve gözlerde lokalize olmuştur. Gastrointestinal mikrobiyomun, koruyucu, metabolik ve yapısal faydaları vardır.

Mikrobiyotanın ise, konakçıda immün yanıtın olgunlaşması ve patojenlerden korunması gibi faydaları vardır. Yapılan çalışmalarda, mikrobiyotanın alerjik hastalıklar, çölyak, obezite ve Tip 1 diyabet gibi hastalıklarının gelişiminde etkisi olduğu düşünülür. Mikrobiyotadaki bakterilerin içeriğinin ve miktarının değişerek dengenin bozulması durumuna disbiyosiz denir. Disbiyozis, bağırsak bariyerinin fonksiyonunu, bazofilleri ve Tip 2 bağışıklığın modülasyonunu etkileyerek alerjik yanıt oluşumuna neden olmaktadır (Johnson ve Ownby, 2017; Zhao ve 
ark., 2019; Berni ve ark., 2019; Kalip ve Atak, 2018; Kurtaran 2021). Yenidoğan ve bebeklik döneminde besin alerjisinde mikrobiyal değişikliği inceleyen bir araştırmada, süt alerjisine sahip bebeklerde Lactobacilli miktarları daha yüksek, Enterobacteria ve Bifidobacteria miktarları ise daha düşük düzeylerde bulunmuştur (Thompson-Chagoyan ve ark., 2010).

\subsection{Hijyen Hipotezi}

1989 yılında ortaya çıkan hijyen hipotezine göre, mikroorganizmalarla temasın azalması şehirleşme ve doğadan uzak kalınmasının, buna bağlı olarak alerjik hastalıkların prevelansının artmasında etken olduğu düşünülmektedir (Strachan, 1989). İmmun sistem hücreleri anne karnından itibaren ve doğum yoluyla oluşmaya başlar. Sezeryan ile olan doğan bebeklerin normal doğan bebeklere göre mikrobiyal maruziyetleri azaldığı için alerji gelişme riski 7 kat daha fazladır (Iweala ve ark., 2016).

T hücresi 1 (Th1) viral enfeksiyonlar tarafından uyarılır. Hava yolu ile bulaşan virüsler ve GíS enfeksiyonları, immun sistemin antijenle karşılaşma ve cevap oluşturmasını artırdığı için alerji gelişim riskini azaltır. Viral antijenler ile erken yaşta karşılaşılmadığında Th1 baskılanır ve Th2 dengesi kurulamaz. Mikrobiyal floranın olmayışı veya az olması durumunda Th1 ve Th2 dengesinde bozulma olur (Ekinci, 2015). Th1/Th2 dengesi çevresel faktörlerden etkilenir. Her iki hücrenin de saldığ sitokinler bir diğerini etkilemektedir (Yıldızdaş, 2016).

Th2 yönüne eğiliminin devam etmesi ileride atopik/alerjik hastalıklara sebep olabilir. Günümüzde aşırı antibiyotik ilaçların kullanımı, fazla hijyenik bir ortamda büyümek ve gelişmiş ve zenginleşmiş ülkelerde beslenme değişiklikleri sonucunda çocukların mikroplarla erken yaşta temaslarının azalması bu duruma katkı yapan nedenlerin başında gelmektedir (Hornig, 2013). Bir makaleye göre perinatal dönemde oluşan mikrobiyota çeşitliliği natürel killer $\mathrm{T}$ lenfositler üzerinde ömür boyu devam eden bir etki meydana getirebilmektedir (Olszak ve ark., 2012). Çocuk ve erişkinlerde alerjik hastalıklarda günümüzdeki bu artışın özellikle sanayileşmiş ülkelerde daha sık rastlanma nedeninin, süt çocuğunun bağırsaktaki yerel ve dolaylı olarak sistemik bağ 1 şıklık sisteminin mikrobiyal uyarılmasının azlığg ile ilişkilendirilmektedir ve bu durumun tipik Batı'lı yaşam tarzından gelen abartılı hijyene bağlı olduğu sanılmaktadır (Cabana, 2007). Son yıllarda gelişmiş batı ülkelerinde yapılan çalışmalar, atopik hastalıkların insidans ve prevalansında önemli bir artış olduğunu göstermektedir (Zeyrek ve Zeyrek, 2006).

\section{2.Çocuk Yaşta Geçirilen Enfeksiyonlar}

Sitopatik etki gösteren Adeno virüs ve RSV gibi etkenlerin neden olduğu viral enfeksiyonların, alerji ve astımı tetiklemesinde etken olduğu rapor edilmiştir. Bunun nedeni; antijenlerin, immun sistem hücreleri tarafından işlenmeden, hasarlı bölgeden doğrudan dolaşım sistemindeki lenfositlere ulaşması olduğu düşünülür. Gelişmiş ülkelerde alerjik bireylerin sayısının artış göstermesi ve buna zıt olarak da gelişmekte olan ülkelerdeki bireylerde daha az alerjik birey varlığı ve sitokin cevabı arasındaki farklılıklar, hijyen hipotezini destekler niteliktedir (Ekinci, 2015).

\subsection{Besin Alerjisinde Beslenme ve Mikrobiyom}

Besin alerjisindeki ani artış, beslenme ve bağırsak mikrobiyotası hastalık patogenezinde önemli rol oynar. Katı gıdaların erken girişi, mikrobiyotanın dayanıklı ağız toleransı sağladığı bir zaman olan "sütten kesme reaksiyonu" ile senkronize olur. Son çalışmalar, besin alerjisi olan çocukların Clostridiales türlerinin kaybı ile erken başlangıçlı bir disbiyosiz gösterdiğini ve bunun da ROR- $\gamma \mathrm{t}+$ ' nın farklılaşmasını teşvik ettiğini göstermiştir (Stephen-Victor ve ark., 2020).

Beslenme, bağırsak mikrobiyota çeşitliliğini ve fonksiyonunu etkileyen ana çevresel faktörlerden biri olarak kabul edilir. Beslenme, erken yaşamda önemli bir çevresel faktördür ve bağışıklık sisteminin olgunlaşmasını ve gelişmesini çeşitli şekillerde etkileyebilir. Mckenzie ve arkadaşları (2017), "beslenme-bağırsak mikrobiyom-fizyoloji ekseni" ni diyet, bağırsak mikrobiyotası ve alerjik hastalık arasında temel bir bağlantı olarak tanımlar (McKenzie ve ark., 2017).

Roduit ve arkadaşları (2019), bir doğum kohortundan 1 yaşındaki 301 çocuğun dışkı örneklerinde kısa zincirli yağ asitlerinin (KZYA) seviyelerini analiz etmişlerdir. Bir yaşında en yüksek bütirat ve propiyonat seviyelerine sahip çocukların 3 ve 6 yaşlarında astım hastalığına yakalanma olasılıklarının daha düşük olduğunu bildirmişlerdir. Bu çocuklar ayrıca, önemli ölçüde daha az alerjik duyarlılık ve gıda alerjisi ile alerjik rinit teşhisi risklerinde azalma göstermiştir. Araştırmalar, artan KZYA düzeylerinin çocuklarda alerjik hastalığg önlemek için bir seçenek olabileceğini göstermektedir (Roduit ve ark., 2019). Evde hazırlanan sebze, meyve ve lifli diyetin, Bifidobacterium gibi bakterilerin çoğalmasını sağlayarak kısa zincirli yağ asitleri (KZYA) seviyelerinde bir artış sağladığı bilinmektedir. Tan ve arkadaşları (2016), Bifidobacterium türlerinin azalan seviyelerini, alerji riskinin artmasıyla ilişkilendirmektedir (Tan ve ark., 2016).

Besin alerjisinin gelişmesinde çeşitli diyet faktörlerinin anahtar rol oynadığı görülmektedir. Roduit ve arkadaşları (2014), bir doğum kohort çalışmalarında, 856 çocuğun yaşamlarının ilk yılında beslenme uygulamalarını araştırırken, ileriye dönük olarak çevresel faktörler ve alerjik hastalık gelişimi hakkında veri toplamıştır. Yaşamın ilk yılında başlatılan tamamlayıcı gıda çeşitliliğinin artmasının, 6 yaşına kadar gıda alerjisi ve gıda duyarlılığı gelişimi ile ters ilişkili olduğunu bildirmişlerdir. Sunulan her ek gida maddesi ile bir doz-yanıt etkisi de not edilmiştir. Çeşitli diyetlerin gıda alerjisi gelişimine karşı koruyucu bir etkisi olduğunu düşünmektedirler (Roduit ve ark., 2014).

2019 yılında Cait ve arkadaşları tarafindan yapılan bir çalışmada, erken bebeklik döneminde bağırsaktaki bakteriyel bütirat üretiminin çocuklarda atopik hastalık gelişimine karşı koruyucu olup olmadığı araştırılmıştır. Çalışmanın sonucunda, alerjik duyarlılık geliştirmeye devam eden bebeklerin mikrobiyomunda hem karbonhidrat parçalanması hem de bütirat üretimi için anahtar enzimleri kodlayan genlerden yoksun olduğunu bulmuşlardır (Cait ve ark., 2019).

Araştırmalar beslenmenin az bir zaman aralığında bağırsak mikrobiyotasında önemli değişikliklere yol açabileceği göstermiştir. Tıbbi beslenme tedavisiyle birlikte bağırsak mikrobiyotası arasındaki ilişki daha fazla araştırılmalıdır (Mercan ve Özel, 2019). 


\section{Besin Alerjilerinin Doğal Seyri ve Besin Alerjenleri ile Çapraz Reaksiyon}

\begin{tabular}{|c|c|c|c|}
\hline Besin & Başlama Yaşı & Çapraz Reaksiyon & Düzelme Yaşı \\
\hline Yumurta beyazı (Tavuk) & $6-24$ ay & Diğer yumurtalar & 7 yaş (\%75 hasta düzelir) \\
\hline İnek sütü & $6-12$ ay & Koyun, keçi ve manda & 5 yaş (\%76 hasta düzelir) \\
\hline Fistık & $6-24$ ay & Baklagiller, ağaç fistıkları & $\begin{array}{l}\text { Yaşam boyu devam eder } \\
\text { (\%20 hasta } 5 \text { yaşa kadar } \\
\text { düzelir) }\end{array}$ \\
\hline Ağaç fıstıkları & $\begin{array}{l}1-7 \text { yaş erişkinlerde huş } \\
\text { poleni ile çapraz reaksiyon }\end{array}$ & $\begin{array}{l}\text { Fistık ve diğer ağaç } \\
\text { fistıkları }\end{array}$ & $\begin{array}{l}\text { Yaşam boyu devam eder } \\
\text { (\%9 hasta } 5 \text { yaşa kadar } \\
\text { düzelir) }\end{array}$ \\
\hline Susam & 6-36 ay & Fistık ve ağaç fistıkları & $\begin{array}{l}\text { Yaşam boyu devam eder } \\
\text { (\%9 hasta } 7 \text { yaşa kadar } \\
\text { düzelir) }\end{array}$ \\
\hline Balık & Genç, çocuk erişkinlik & Bütün balıklar & Yaşam boyu devam eder \\
\hline Deniz ürünleri & Erişkin dönemi 6-24 ay & Diğer deniz ürünleri & Yaşam boyu devam eder \\
\hline Buğday & $6-24$ ay & Gluten içeren tahıllar & $\begin{array}{l}\text { Gluten içeren tahıllar } 5 \text { yaş } \\
\text { (\%80 hasta düzelir) }\end{array}$ \\
\hline Soya & $6-24$ ay & Baklagiller & 2 yaş (\%67 hasta düzelir) \\
\hline Kivi & Herhangi bir yaş & Muz, avokado, latex & Bilinmiyor \\
\hline *Elma, havuç, şeftali & Geç çocukluk, erişkin & $\begin{array}{l}\text { Birch polen, diğer } \\
\text { meyveler, fistıklar }\end{array}$ & Bilinmiyor \\
\hline
\end{tabular}

\subsection{Probiyotiklerin Rolü}

Probiyotikler, bariyer işlevini iyileştirerek, potansiyel patojenlerle etkileşerek, immünomodülasyon ve nörotransmiterlerin üretiminde bağırsak-beyin ekseninin hücresel bileşenlerine kadar değişik yollarla konakçıya dört temel mekanizma yoluyla fayda sağlamaktadır (Sánchez ve ark., 2017).

Probiyotiklerin immünomodülatör etkileriyle, alerji gibi immünolojik hastalıklarda yararlı etkileri vardır (Kim ve ark., 2014; Di Costanzo ve ark., 2016). Probiyotik metaboliti olan kısa zincirli yă̆ asitleri, periferik Treg hücre sayısını ve işlevinin düzenlenmesinde yarar sağlar. KZYA kolonda yer alan Foxp3+ ile Treg hücrelerin üzerinde bulunan G-protein-bağl1 43 reseptörünü (GPR43) aktive ederek yarar sağlar (Furusawa ve ark., 2013; Milligan ve ark., 2014).

Probiyotikler, Th1 yanıtın1 artırarak Th1/Th2 dengesini sağlamaktadır ve Th2'den IgE üretimini ve IL6, IL10, IL4 salınımını baskılayarak alerjik hastalıkların oluşumunu baskılamaktadır (Koshksaray ve ark., 2020). Yapılan bir çalışmada besin alerjili fare modelinde Anaerostipes caccae ile doyurulan farelerde alerjik semptomlar azaltmıştır (Feehley ve ark., 2019). Yapılan başka bir çalışmada ise, Clostridiales türleri verilen farelerde besin alerjisinin önlenmesine katkı sağlanmıştır (Abdel-Gadir ve ark., 2019; Akyüz ve Sürücü, 2020).

191 gebeden (LGG grubu (Lactobacillus verilen), $\mathrm{n}=95$; kontrol grubu, $n=96$ ) oluşan bir popülasyonda, erken çocukluk ve maternal alerjik hastalıkların önlenmesinde prenatal ve postnatal probiyotiklerin etkinliği araştırılmıştır. Gebeliğin ikinci e-ISSN: 2148-2683 trimesterinde başlayan LGG uygulamasının, Th1 yanıtının artmasıyla maternal alerjik hastalığın şiddetini azalttığı fakat çocukluk çağı alerjik duyarlılığı veya alerjik hastalıkların insidansını azaltmadığı sonucuna ulaşılmıştır (Ou ve ark., 2012).

\subsection{Fekal Mikrobiyota Transplantasyonu/ Fekal Bakteriyoterapi}

Mikrobiyota; birçok hastalık ve besin alerjileri açısından önemli rol oynamaktadır. Fekal Mikrobiyota Transplantasyonu (FMT) bağırsak mikrobiyotasının geliştirilmesi, tip 2 bağışıklık modülasyonun geliştirilmesi ve bağırsak bariyerinin onarılması amacıyla uygulanan bir tedavi yöntemidir.

FMT "sağlıklı bireyden alınan gaitanın çeşitli işlemlerden geçirilerek, suspansiyon haline getirilmesi" ve hasta bireyin intestinal lümenine çeşitli yollar ile (nazoduodenal/nazojejunal sonda, enema, jejunoskopi, gastroskopi veya kolonoskopi) verilmesi işlemidir. Yapılan bir deneyde, besin alerjisine sahip bir fareye sağlıklı bir bebekten yapılan bir FMT işlemi ile alerjen maruziyet sonrası gelişen anafilaksinin önüne geçilebilmiştir. $\mathrm{Bu}$ olumlu etkileri ile FMT tedavisi, umut vaat eden bir tedavi olarak görülmektedir. FMT'nin tıbbi literatürdeki diğer isimleri, fekal bakteriyoterapi, gaita transplantasyonu ve fekal transfüzyondur (Abdel-Gadir ve ark., 2019; Uygun, 2017; Demirci, 2019).

\subsection{Prebiyotikler}

Prebiyotik, konak mikroorganizmalar tarafından seçici olarak kullanılan sağlığa faydalı bir substrattır. Fruktooligosakkaritler (FOS), galaktooligosakkaritler (GOS), inülin, laktuloz ve 
polidekstroz gelişmiş prebiyotikler sınıfında bulunurken, izomaltooligosakkaritler (IMO), ksilooligosakkaritler ve laktitol ise gelişmekte olan prebiyotikler sınıfindadır (Demirci ve ark., 2017). Prebiyotikler, ince bağırsak enzimlerince sindirilemeyerek kolona geçmektedir ve burada bulunan bakteriler tarafindan fermente olmaktadir. Prebiyotikler, kolondaki bakterilerin aktivitelerini seçici olarak uyararak konakçıya faydalı olan bakterilerin gelişimini sağlamaktadır (Haarman ve Knol, 2006). Prebiyotiklerin karbon kaynağı olarak kullanılmasıyla, asetik asit, laktik asit, bütirik asit ve propiyonik asit gibi KZYA oluşur. KZYA bağırsak pH'ını düşürür ve böylece, mineral ve kalsiyum emilimi artar (Saad ve ark., 2013; Bakır, 2012).

\subsection{Sinbiyotikler}

Probiyotikler ve prebiyotiklerin sinerji içerisinde birlikte hareket etmek üzere birleştirilmesine, "sinbiyotik" denmektedir. En iyi sinerjik etki gösteren sinbiyotikler ise Bifidobacterium suşları+FOS, Bifidobacterium suşları+GOS, Lactobacillus suşları+laktilol, kombinasyonlarıdır (Gülmez ve Güven, 2002). Sinbiyotiklerin immünomodülatör, antialerjik, antimikrobiyal, antikarsinojenik, hipolipidemik ve hipoglisemik etkileri bildirilmiştir Chang ve arkadaşlarının (2016) yapmış olduğu bir araştırmada, 1 yaş ve üzeri çocuklarda atopik dermatit tedavisi için, özellikle karışık bakteri suşlarından oluşan sinbiyotiklerin kullanımını önerilmektedir (Chang ve ark., 2016).

\section{Sonuç}

- Gelişmiş ülkelerde son yıllarda besin alerjilerinin görülme sıklığı giderek artmaktadır.

- Ailede atopi öyküsünün dışında, tamamlayıcı beslenmeye geçiş, sezaryenle doğum, hijyen hipotezi ve disbiyosiz varlığ arasındadir.

- Mikrobiyota besin alerjilerinde fizyolojik olarak koruyucu işlevleri düzenlemektedir.

- Probiyotikler immünomodülatör etki göstererek, alerji ve immünolojik hastalıkların mekanizmalarına olumlu katkılar sağlamaktadır.

- Besin alerjilerinin ülkemizdeki sıklığının saptanması, risk altındaki bireylerin saptanması, gıda güvenliğin sağlanmas1, toplumun bilinçlendirilmesi ve koruyucu önlemlerin alınması gerekmektedir.

- Tıbbi beslenme tedavisiyle birlikte bağırsak mikrobiyotası arasındaki ilişki daha fazla araştırılmalıdır.

\section{Kaynakça}

Abdel-Gadir, A., Stephen-Victor, E., Gerber, G. K., Rivas, M. N., Wang, S., Harb, H., ... \& Chatila, T. A. (2019). Microbiota therapy acts via a regulatory $\mathrm{T}$ cell MyD88/ROR $\gamma \mathrm{t}$ pathway to suppress food allergy. Nature medicine, 25(7), 1164-1174.

Akan A. (2016).Alerji Testleri. Aslan A, Kiper N, editörler. Çocuk Göğüs Hastalıklarında Tanı Yöntemleri. 1. Baskı: İstanbul. Probiz Ltd. Şti. (Content Ed Net Türkiye), 65-77.

Akay, E., \& Yılmaz, İ. (2020). Yeni Etiketleme Yönetmeliğine Göre Alerjen Gidalar ve Sağlık Etkileri.

e-ISSN: 2148-2683
Akbulut, G. (2016). Tibbi Beslenme Tedavisinde Güncel Uygulamalar 1. Besin Alerjisi, Besin İntoleransı Durumlarında Beslenme ve Test Diyetleri. (Gözden geçirilmiş ikinci baskı). Ankara: Ankara Nobel Tip Kitabevi.

Akoğlu, A., \& Oruç, M. (2018). Metabolik Gıda İntoleransları. Harran Tarım ve Gida Bilimleri Dergisi, 22(2), 284295.https://doi.org/10.29050/harranziraat.296641

Akyüz, E. Y., \& Sürücü, Y. (2020). Fekal mikrobiyota transplantasyonu ve hastalıklar üzerine etkileri. Sağlık Akademisyenleri Dergisi, 7(4), 296-303.

Akyüz, H. C. (2018). Besin Alerjisi Olan Çocukların Beslenme Durumunun Değerlendirilmesi.

Anvari, S., Miller, J., Yeh, C. Y., \& Davis, C. M. (2019). IgEmediated food allergy. Clinical reviews in allergy \& immunology, 57(2), 244-260.

Bakır, B. O. (2012). Prebiyotik, Probiyotik ve Sinbiyotiklere Genel Bakış. Beslenme ve Diyet Dergisi, 40(2), 178-182.

Bayram, G. (2011). Bursa ili 6-14 yaş grubu çocuklarda besin alerjisi ve semptomlarının sıklığı.

Begen, F. M., Barnett, J., Barber, M., Payne, R., Gowland, M. H., \& Lucas, J. S. (2017). Parents' and caregivers' experiences and behaviours when eating out with children with a food hypersensitivity. BMC Public Health, 18(1). https://doi.org/10.1186/s12889-017-4594-z

Boyce, JA, Assa'ad, A., Burks, AW, Jones, SM, Sampson, HA, Wood, RA, ... \& Schwaninger, JM (2011). Amerika Birleşik Devletleri'nde gıda alerjisinin teşhisi ve yönetimi için kılavuzlar: NIAID sponsorluğundaki uzman paneli raporunun özeti. Amerikan Dermatoloji Akademisi Dergisi, 64 (1), 175-192.

Cait, A., Cardenas, E., Dimitriu, P. A., Amenyogbe, N., Dai, D., Cait, J., ... \& Mohn, W. W. (2019). Reduced genetic potential for butyrate fermentation in the gut microbiome of infants who develop allergic sensitization. Journal of Allergy and Clinical Immunology, 144(6), 1638-1647.

Canani, R. B., Gilbert, J. A., \& Nagler, C. R. (2015). The role of the commensal microbiota in the regulation of tolerance to dietary allergens. Current opinion in allergy and clinical immunology, 15(3), 243.

Canani, R. B., Paparo, L., Nocerino, R., Di Scala, C., Della Gatta, G., Maddalena, Y., ... \& Ercolini, D. (2019). Gut microbiome as target for innovative strategies against food allergy. Frontiers in immunology, 10, 191.

Chang Y, Trivedi MK, Jha A, Lin Y, Dimaano L, Garcia-Romero MT. (2016). Synbiotics for Prevention and Treatment of Atopic Dermatitis A Meta-analysis of Randomized Clinical Trials. JAMA Pediatrics, 170(3):236 242. doi:10.1001/jamapediatrics.2015.3943.

De Martinis, M., Sirufo, M. M., Suppa, M., \& Ginaldi, L. (2020). New perspectives in food allergy. International journal of molecular sciences, 21(4), 1474.

Demir, E.(2019) Alerjik Hastanın Beslenmesine Akılcı Yaklaşım. Klinik Tip Pediatri Dergisi, 11(2), 94-102.

Demir, E., \& Ulusoy, E. (2017). Evaluation of Food Allergies. Klinik Tip Pediatri Dergisi, 9, 74-77.

Demirci, M., Sağdıç, O., Çavuş, M., Pehlivanoğlu, H., Yılmaz, M. T., \& Çăglar, M. (2017). Prebiyotik oligosakkaritlerin kaynakları, üretimleri ve gida uygulamaları. Avrupa Bilim ve Teknoloji Dergisi, 6(10), 20-31.

Demirci, H. (2019). Fekal Mikrobiyota Transplantasyonu. Tip Fakültesi Klinikleri Dergisi, 2(4) , 127-129. Retrieved from http://dergipark.org.tr/en/pub/atk/issue/51601/668447.

Di Costanzo, M., Amoroso, A., \& Canani, R. B. (2016). Gut microbiota as a target for food allergy. Journal of pediatric gastroenterology and nutrition, 63(1S), S11-S13.

Dyer, A. A., \& Gupta, R. (2013). Epidemiology of childhood food allergy. Pediatric Annals, 42(6), 91-95. https://doi.org/10.3928/00904481-20130522-08 
Ekinci, B. Besin Allerjisi Ve Dört Hipotez. 21 Mayıs 2015, 9.

Epöztürk K.,(2021) Besin Duyarlılığı S1klığı Nedir? https://istanbulalerjimerkezi.com.tr/yetiskinlerde-besin-alerjisisikligi/ [Erişim tarihi 01.03.2021]

Faber, M. A., van Gasse, A. L., Decuyper, I. I., Sabato, V., Hagendorens, M. M., Mertens, C., Bridts, C. H., de Clerck, L. S., \& Ebo, D. G. (2018). Cross-Reactive Aeroallergens: Which Need to Cross Our Mind in Food Allergy Diagnosis? Journal of Allergy and Clinical Immunology: In Practice, 6(6), 1813-1823. https://doi.org/10.1016/j.jaip.2018.08.010

Feehley, T., Plunkett, C. H., Bao, R., Hong, S. M. C., Culleen, E., Belda-Ferre, P., ... \& Nagler, C. R. (2019). Healthy infants harbor intestinal bacteria that protect against food allergy. Nature medicine, 25(3), 448-453.

Floch, M. H., \& Narayan, R. (2002). Diet in the Irritable Bowel Syndrome. In J Clin Gamoenferol. Lippincott Williams \& Wilkins, Inc. http://journals.lww.com/jcge

Frith K, Katelaris CH. (2019). Current perspectives on peanut allergy. internal Medicine Journal. 12:1480-7.

Furusawa, Y., Obata, Y., Fukuda, S., Endo, T. A., Nakato, G., Takahashi, D., ... \& Ohno, H. (2013). Commensal microbederived butyrate induces the differentiation of colonic regulatory T cells. Nature, 504(7480), 446-450.

Gübür, S. (2012). Besin intoleransı saptanan kilolu ve obez kişilere uygulanan eliminasyon diyetinin, vücut kompozisyonu ve biyokimyasal parametrelere etkisinin belirlenmesi (Master's thesis, İstanbul Bilim Üniversitesi, Sağlık Bilimleri Enstitüsü).

Gülmez, M. ve Güven, A. (2002). Probiyotik, prebiyotik ve sinbiyotikler. Kafkas Üniversitesi Veterinerlik Fakültesi Dergisi, 8, 83-89.

Güzelsoy, N. A. (2021). Badem ve findıktaki alerjen peptidlerin proteomiks tekniği kullanılarak tespiti ve isıl işlem sonrası alerjenlerin stabilitesinin araştırılması.

Haarman, M., \& Knol, J. (2006). Quantitative real-time PCR analysis of fecal Lactobacillus species in infants receiving a prebiotic infant formula. Applied and Environmental microbiology, 72(4), 2359-2365.

Ho, M. H. K., Wong, W. H. S., \& Chang, C. (2014). Clinical spectrum of food allergies: a comprehensive review. Clinical reviews in allergy \& immunology, 46(3), 225-240.

Hornig M (2013) The role of microbes and autoimmunity in the pathogenesis of neuropsychiatric illness. Curr Opin Rheumatol, 25:488-795.

Iweala, OI ve Burks, AW (2016). G1da alerjisi: patogenezi, önlenmesi ve tedavisi ile ilgili gelişen anlayışımız. Güncel alerji ve astım raporları, $16(5), 37$.

Johansson, S. G. O., Bieber, T., Dahl, R., Friedmann, P. S., Lanier, B. Q., Lockey, R. F., Motala, C., Ortega Martell, J. A., Platts-Mills, T. A. E., Ring, J., Thien, F., van Cauwenberge, P., \& Williams, H. C. (2004). Revised nomenclature for allergy for global use: Report of the Nomenclature Review Committee of the World Allergy Organization, October 2003. Journal of Allergy and Clinical Immunology, 113(5), 832-836. https://doi.org/10.1016/j.jaci.2003.12.591

Johnson, C. C., \& Ownby, D. R. (2017). The infant gut bacterial microbiota and risk of pediatric asthma and allergic diseases. Translational Research, 179, 60-70.

Johnston, L. K., Chien, K. B., \& Bryce, P. J. (2014). The immunology of food allergy. The Journal of Immunology, 192(6), 2529-2534.

Kalip, K., \& Atak, N. (2018). Bağırsak mikrobiyotası ve sağlık. Turkish Journal of Public Health, 16(1), 58.

Keet C, \& Wood R. (2011). Overview of mucosal immunity and development of oral tolerance. In B. A. E. P. James JM (Ed.), In Food Allergy (pp. 31-undefined).
Khanna S, Tosh PK (2014) A clinican's primer on the role of the microbiome in human health and disease. Mayo Clin Proc, 89:107- 114

Kim, H. J., Kim, Y. J., Lee, S. H., Yu, J., Jeong, S. K., \& Hong, S. J. (2014). Effects of Lactobacillus rhamnosus on allergic march model by suppressing Th2, Th17, and TSLP responses via CD4+ CD25+ Foxp3+ Tregs. Clinical immunology, 153(1), 178-186.

Koca, T., \& Akçam, M. (2015). İnek sütü protein alerjisi. Dicle Medical Journal / Dicle Tip Dergisi, 42(2). https://doi.org/10.5798/diclemedj.0921.2015.02.0572

Koshksaray, F. K., Özbalak, M. M., Balkan, İ. İ., \& Yurdagül, G. E. Gıda Kaynaklı İmmünomodülatörler. Experimed, 10(2), 97-111.

Krogulska A, Wood RA.(2020). Peanut allergy diagnosis: Moving from basic to more elegant testing. Pediatric Allergy and 1mmunology. 31(4):346-57.

Kurtaran, B. (2021). Mikrobiyom ve mikrobiyota. Ege Tip Dergisi, 88-93.

Kvenshagen, B., Halvorsen, R., \& Jacobsen, M. (2009). Is there an increased frequency of food allergy in children delivered by caesarean section compared to those delivered vaginally?. Acta Paediatrica, 98(2), 324-327.

Lee, S. (2017). Çocuklarda IgE aracılı gıda alerjileri: yaygınlık, tetikleyiciler ve yönetim. Kore pediatri dergisi, 60 (4), 99.

Loh, W., \& Tang, M. L. (2018). The epidemiology of food allergy in the global context. International journal of environmental research and public health, 15(9), 2043.

Lopes, J. P., \& Sicherer, S. (2020). Food allergy: epidemiology, pathogenesis, diagnosis, prevention, and treatment. Current Opinion in Immunology, 66, 57-64. https://doi.org/10.1016/j.coi.2020.03.01

McKenzie, C., Tan, J., Macia, L., \& Mackay, C. R. (2017). The nutrition-gut microbiome-physiology axis and allergic diseases. Immunological reviews, 278(1), 277-295.

Mercan, S., \& Özel, H. G. (2019). Çocukluk Çağ1 Kronik Hastalıklarında Tıbbi Beslenme Tedavisi Bağırsak Mikrobiyotasını Etkiler mi? . Beslenme ve Diyet Dergisi, 47(3), 67-75.

Mısırlığlu ED, Bostancı İ. Besin Alerjisi. Türkiye Çocuk Hast Derg/Turkish J pediatr Dis /2013: 4: 206-213.

Milligan, G., Ulven, T., Murdoch, H., \& Hudson, B. D. (2014). Gprotein-coupled receptors for free fatty acids: nutritional and therapeutic targets. British journal of nutrition, 111(S1), S3-S7.

Molloy, J., Allen, K., Collier, F., Tang, M. L., Ward, A. C., \& Vuillermin, P. (2013). The potential link between gut microbiota and IgE-mediated food allergy in early life. International journal of environmental research and public health, 10(12), 7235-7256.

Muraro, A., Werfel, T., Hoffmann-Sommergruber, K., Roberts, G., Beyer, K., Bindslev-Jensen, C., ... \& EAACI Food Allergy and Anaphylaxis Guidelines Group. (2014). EAACI food allergy and anaphylaxis guidelines: diagnosis and management of food allergy. Allergy, 69(8), 1008-1025.

Ng, S. C., Hart, A. L., Kamm, M. A., Stagg, A. J., \& Knight, S. C. (2009). Mechanisms of action of probiotics: recent advances. Inflammatory bowel diseases, 15(2), 300-310.

Nwaru, B. I., Hickstein, L., Panesar, S. S., Roberts, G., Muraro, A., \& Sheikh, A. (2014). Prevalence of common food allergies in Europe: A systematic review and meta-analysis. In Allergy: European Journal of Allergy and Clinical Immunology (Vol. 69, Issue 8, pp. 992-1007). Blackwell Publishing Ltd. https://doi.org/10.1111/all.12423

Olszak T, An D, Zeissig S, Vera MP, Richter J, Franke A et al. (2012) Microbial exposure during early life has persistent effects on natural killer T cell function. Science, 336:489-493.

Ou, C. Y., Kuo, H. C., Wang, L., Hsu, T. Y., Chuang, H., Liu, C. A., ... \& Yang, K. D. (2012). Prenatal and postnatal probiotics reduces maternal but not childhood allergic diseases: a 
randomized, double-blind, placebo-controlled trial. Clinical \& Experimental Allergy, 42(9), 1386-1396.

Özcan, T., Delikanlı, B., \& Yıldız, E. (2015). Gıda işleme yöntemlerinin gida alerjenitesi üzerine etkisi. Uludağ Üniversitesi Ziraat Fakültesi Dergisi, 29(2).

Özçeker, D., \& Tamay, Z. (2015). Çocuklarda inek sütü alerjisine yaklaşım. İstanbul Bilim Üniversitesi Florence Nightingale Tıp Dergisi, 1(2), 108-114.

Özçelik, Ö. (2019). Besin Alerjilerinde Tanı Testleri (Taha Gökmen Ülger, Ayşe. Academic Studies on Natural and Health Sciences, 275.

Öztürk, U. D. M., \& Besler, H. T. (2012). Besin alerjileri. Sağlık bakanlığı yayınları. Ankara.

Paykoç E. (2017).Gıda Alerjisi, Gıda Alerjisinin Mekanizması, Tanı Yöntemleri ve Alerjinitesinin Azaltılmasında Kullanılan Teknikler [Lisans Tezi]. Trabzon, Türkiye: Gıda Mühendisliği Bölümü, Avrasya Üniversitesi Mühendislik ve Mimarlık Fakültesi.

Prescott, S. L., Pawankar, R., Allen, K. J., Campbell, D. E., Sinn, J. K., Fiocchi, A., Ebisawa, M., Sampson, H. A., Beyer, K., \& Lee, B.-W. (2013). A global survey of changing patterns of food allergy burden in children. http://www.waojournal.org/content/6/1/21.

Prescott, S.L., Macaubas, C., Holt BJ, Smallacombe TB, Loh R, Sly PD, et al. (1998) Transplacental priming of the human immune system to environmental allergens: universal skewing of initial $\mathrm{T}$ cell responses toward the Th2 cytokine profile. J Immunol; 160 (10): 4730-4737.

Roduit, C., Frei, R., Depner, M., Schaub, B., Loss, G., Genuneit, J., ... \& PASTURE study group. (2014). Increased food diversity in the first year of life is inversely associated with allergic diseases. Journal of allergy and clinical immunology, 133(4), 1056-1064.

Roduit, C., Frei, R., Ferstl, R., Loeliger, S., Westermann, P., Rhyner, C., ... \& Doekes, G. (2019). High levels of butyrate and propionate in early life are associated with protection against atopy. Allergy, 74(4), 799-809.

Saad, N., Delattre, C., Urdaci, M., Schmitter, J. M., \& Bressollier, P. (2013). An overview of the last advances in probiotic and prebiotic field. LWT-Food Science and Technology, 50(1), 1-16.

Sackesen, C., Altıntaş, DU, Bingol, A., Bingol, G., Büyüktiryaki, B., Demir, E., ... \& Şekerel, BE (2019). İnek sütü alerjisinde tolerans indüksiyonundaki mevcut eğilimler: pasif stratejilerden proaktif stratejilere. Pediatride Sinırlar, 7, 372.

Sampson HA, \& Burks AW. (2009). Middleton's Allergy Principles \& Practice. 67-1139.

Sampson, H. A. (2004). Update on food allergy. Journal of allergy and clinical immunology, 113(5), 805-819.

Sánchez, B., Delgado, S., Blanco-Míguez, A., Lourenço, A., Gueimonde, M., \& Margolles, A. (2017). Probiotics, gut microbiota, and their influence on host health and disease. Molecular nutrition \& food research, 61(1), 10.1002/mnfr.201600240. https://doi.org/10.1002/mnfr.201600240

Satitsuksanoa, P., Jansen, K., Głobińska, A., van de Veen, W. ve Akdis, M. (2018). Gıda alerjisine toleransta düzenleyici bağışıklık mekanizmaları. İmmünolojide Sınırlar, 9, 2939.

Seth, D., Poowutikul, P., Pansare, M., \& Kamat, D. (2020). Food allergy: A review. Pediatric annals, 49(1), e50-e58. https://doi.org/10.3928/19382359-20191206-01

Shroba, J., Rath, N., \& Barnes, C. (2019). Possible role of environmental factors in the development of food allergies. Clinical reviews in allergy \& immunology, 57(3), 303-311.

Sicherer, S. H., \& Sampson, H. A. (2018). Food allergy: a review and update on epidemiology, pathogenesis, diagnosis, prevention, and management. Journal of Allergy and Clinical Immunology, 141(1), 41-58.
Stephen-Victor, E., Crestani, E., \& Chatila, T. A. (2020). Dietary and Microbial Determinants in Food Allergy. Immunity, 53(2), 277289.

Strachan DP, 1989. Hay fever, hygiene, and household size. BMJ., 299:1259-1260.

Szépfalusi, Z., Spiesz, K., \& Huttegger, I. (2015). Diagnostik und Management von Nahrungsmittelallergien im Kindes-und Jugendalter. Wiener Medizinische Wochenschrift, 165(17), 354360.

Tan, J., McKenzie, C., Vuillermin, P. J., Goverse, G., Vinuesa, C. G., Mebius, R. E., ... \& Mackay, C. R. (2016). Dietary fiber and bacterial SCFA enhance oral tolerance and protect against food allergy through diverse cellular pathways. Cell reports, 15(12), 2809-2824.

Thompson-Chagoyan, O. C., Vieites, J. M., Maldonado, J., Edwards, C., \& Gil, A. (2010). Changes in faecal microbiota of infants with cow's milk protein allergy-a Spanish prospective case-control 6-month follow-up study. Pediatric Allergy and Immunology, 21(2p2), e394-e400.

Tokuç, R. (2017). Gıda Intoleransının 30-45 Yaş Arası Sedanter Bireyler Üzerindeki Fiziksel ve Ruhsal Etkileri (Master's thesis, İstanbul Gelişim Üniversitesi Sağlık Bilimleri Enstitüsü).

Türkiye İstatistik Kurumu (2016). Türkiye Sağlık Araştırması. http://www.tuik.gov.tr/PreHaberBultenleri.do?id=18854.

Türkiye Ulusal Alerji ve Klinik İmmunoloji Derneği. (2021). Alerjenler. https://www.aid.org.tr/hastaliklar/alerji/alerjenler/ [Erişim Tarihi 01.03.2021]

Ulaş Kadığ̆lu, B. (2017). Artan Gıda Hipersensitivitesi Sıklığının Epidemiyolojik Olarak Değerlendirilmesi. The Journal of Academic Social Sciences, 63(63), 184-192. https://doi.org/10.16992/asos.13282

Uygun, A. (2017). Fekal Mikrobiyota Transplantasyonu (FMT). Journal of Biotechnology and Strategic Health Research, 1, 132-140.

Yazıcı, M., \& Özkaya, E. (2020) Çocuklarda Besin Alerjinerine Yaklaşım. Klinik Tıp Pediatri Dergisi, 12(2), 85-95.

Yıldız, D. (2021). Sesamum İndicum L.(Susam) X Papaver Somniferum L.(Haşhaş) Arasındaki Çapraz Reaksiyonların Western Blot Yöntemi İle Gösterilmesi.

Yıldızdaş, H. Y. (2016) Probiyotikler ve Çocuklarda Bağışıklık Sistemi. Klinik Tıp Pediatri Dergisi, 8(3), 5-10.

Yürük, A. A. (2020). Besin Alerjisi, Besin İntoleransı, Çölyak Hastalığı ve Tıbbi Beslenme Tedavisi. In Prof. Dr. Nevin Şanlıer (Ed.), Yetişkin Hastalıklarında Tıbbi Beslenme Tedavisi Kitabı (pp. 310-327).

Zeyrek, F. Y., \& Zeyrek, C. D. (2006) Alerjik Hastalıklar ve Parazitoz.

Zhao, W., Ho, H. E., \& Bunyavanich, S. (2019). The gut microbiome in food allergy. Annals of Allergy, Asthma \& Immunology, 122(3), 276-282. 